\title{
ANALISIS PENGARUH LAMA USAHA, USIA DAN PENDIDIKAN TERHADAP PENDAPATAN PENGELOLA UMKM KABUPATEN KULON PROGO YOGYAKARTA
}

\author{
Sukardi \\ Universitas Ahmad Dahlan \\ e-mail: sukardi_feuad@yahoo.com
}

\begin{abstract}
ABSTRAK
This study aims to determine the effect of a length of business, age and education, to UMKM managers income in kabupaten of Kulonprogo. Its population is around the UMKM managers in Kulonprogo, obtained a sample of 83 respondents with a purposive sampling technique. Simultaneously, the variable length of business, age and education have a positive and significant effect on UMKM managers income in Kulonprogo. Partially, education variable is positive and significant effect on UMKM managers income in Kulonprogo.
\end{abstract}

Keywords: length of business, age, education and UMKM managers income.

\section{PENDAHULUAN}

Pengembangan pembangunan di setiap daerah selalu diawali dengan pengembangan sumber daya manusia (SDM)nya, hal ini sebagai upaya mendorong berkembangnya SDM yang berperan sebagai pelaku, penggerak dan pelaksana pembangunan daeah dalam arti luas. Khusus pembangunan bidang perekonomian, pengembangan SDM diperlukan pendidikan yang cukup, pengalaman dan wawasan berpikir yang luas, wawasan berani mengambil tindakanm (berani berresiko) yang istilah populernya disbut jiwa entrepreneur. Pengelola usaha mikro kecil dan menengah (UMKM) merupakan pelaku-pelaku bisnis di masyarakat yang memerlukan support pengembangan kesuksesan bisnisnya. Secara praktis pengembangan usahanya bertujuan untuk meningkatkan pendapatan sebagai upaya mencapai peningkatan kesejahteraan masyarakat dan penurunan kemiskinan.

Wilayah Kulon Progo yang merupakan kabupaten terendah sumber pendapatannya di antara kelima kabupaten/Kota Madya se Propinsi
Daerah Istimewa Yogyakarta., memerlukan perhatian secara khusus akan pengembangan SDM guna menyongsong perkembangan daerah di masa mendatang, terlebih di era globalisasi yang penuh kompetisi seperti saat ini. Kabupaten Kulon Progo yang terdiri atas 12 kecamatan, 88 desa, ternyata menyimpan segudang potensi swadaya masyarakat lembaga Koperasi dan UMKM di seluruh teritorial daerah di Kulon Progo. Pada kabupaten ini terdapar ratusan UMKM yang tersebar di seluruh daerah, sayangnya UMKM sejumlah itu masih mayoritas usaha kecil dan mikro, dan sangat sedikit yang usahanya memasuki kelas menengah. Hal itu terbukti pengelolaan usaha bertenaga kerja terbatas, banyak yang ditangani keluarga sehingga terkesan usahanya masih sekedar untuk sambilan, bukan pekerjaan pokok yang digarap secara serius sehingga dapat diandalkan menjadi pusat pendapatan utama keluarga. Baru sebagian kecil UMKM yang ditangani sebagai mata pencaharian utama masyarakat.

Kulon Progo yang merupakan kabupaten berbatasan dengan Jawa tengah, sebelah barat 
Kabupaten Purworejo, Sebelah utara berbatasan dengan Magelang, sebelah timur Kabupaten Bantul dan sebelah selatan laut Jawa, mayoritas penduduk berpenghidupan sebagai petani, daerahnya terdiri atas wilayah pertanian untuk Kulon Progo bagian selatan, seperti Galur, lendah, Temon dan wates, lainnya daerah utara merupakan dataran tinggi daerah pegunungan. Kehidupan warga masyarakat daerah seperti ini pada umumnya sangat kuat bergulat dengan tanah dan alam, sehingga memiliki semangat juang yang tinggi untuk bisa mendapatkan pemenuhan kebutuhan hidup sehari hari. Sayangnya karena pengalaman masyarakat terbatas, pengetahuan dan wawasannya terbatas, keuletan yang dimiliki dalam bidang pertanian tradisional yang masih sangat terbatas akan sentuhan bisnis kewirausahaan. Dampaknya masih dalam jumlah terbatas warga yang siap bergulat dengan hidup berwirausaha secara profesional dalam arti usahanya sebagai pusat pengembangan perekonomian, tenaga kerjanya mengerahkan tenaga orang lain di luar keluarga.

Perkembangan usaha pengelolaan UMKM secara individual selalau terwarnai oleh karakter masing-masing individu pengelola, seperti kedisiplinan pemilik, keseriusan pengelolaan pemilik, keberanian menghadapi resiko usaha, inovasi usaha dan pemasarannya dan lain sebagainya. Karakter individu ini terbentuk dari luasnya wawasan dan pengalaman masing-masing individu pengelola UMKM, sehingga semakin lama mengelola UMKM akan dimungkinkan semakin baik karakteistik individu sehingga lebih trampil mengelola UMKM. Semakin tua umur semakin lama berwirausaha, akan semakin bagus kemampuan mengelola UMKM. Demikian pula tingkat pendidikan semakin tinggi dimungkinkan akan semakin luas wawasannya sehingga lebih tinggi tingkat kemampuan mengelola usaha yang berakhir dengan peningkatan pendapatan usaha.
Paradigma yang dibangun pada tulisan ini adalah, bahwa pengelolaan UMKM akan baik diperlukan usia yang lebih dewasa menjadikan pengendapan psikologis, lebih cermat, teliti dan ketelatenan kerja; diperlukan pengalaman mengelola UMKM yang memberikan banyak pertimbangan dalam mengambil kebijakan atas dasar berbagai kasus yang ialami dan memerlukan pendidikan yang lebih tinggi yang dapat memperluas wawasan dalam pengelolaan UMKM, ini semua akan menghasilkan laba atau pendapatan yang lebih tinggi, aset usahanya menjadi besar. Semakin tinggi usia seseorang semakin serius usahanya, semakin tinggi tingkat pendidikan seseorang dan semakin lama pengalaman seseorang akan semakin baik pengelolaan dan akan meningkatkan aset usaha dan pendapatannya.

Atas dasar landasan berpikir di atas, maka problematika yang dikembangkan adalah:

1. Apakah umur, pendidikan dan lama usaha secara bersama-sama berpengaruh terhadap pendapatan para pengelola UMKM di Kabupaten Kulon Progo ?

2. Apakah umur, pendidikan dan lama usaha secara sendiri-sendiri berpengaruh terhadap pendapatan para pengelola UMKM di Kabupaten Kulon Progo ?

Problematika penelitian yang mengandung empat variabel umur, pendidikan, lama usaha dan pendapatan ini menjadi perhatian utama yang akan dibahas pada uraian berikutnya. Variabel-variabel ini juga membatasi ruang lingkup penelitian dan kemudian batas areal penelitiannya pada masyarakat Kabupaten Kulon Progo.

Agar sebuah penelitian termasuk penelitian ini bisa terfokus pada arah tertentu yang jelas, maka penelitian didisain dan ditetapkan tujuan penelitian secara jelas:

1. Untuk mengetahui bahwa umur, tingkat pendidikan dan lama usaha secara bersama- 
sama berpengaruh terhadap pendapatan para pengelola UMKM di Kabupaten Kulon Progo?

2. Untuk mengetahui bahwa umur, tingkat pendidikan dan lama usaha secara parsial berpengaruh terhadap pendapatan pengelola UMKM di Kabupaten Kulon Progo?

\section{REVIEW LITERATUR DAN HIPOTESIS}

Penelitian yang penulis kembangkan pada kesempatan ini meliputi empat variabel yang akan saling keterkaitan antara veriabel dependen dan variabel independen. Keempat variabel dalam penelitian ini, ialah lama usaha, usia pengusaha, tingkat pendidikan dan pendapatan pengelola UMKM. Keterkaitan antara empat variabel ini variabel lama usaha, usia dan pendidikan sebagai variabel bebas (independen) dan variabel pendapatan sebagai variabel terikat (dependen) dapat digambarkan sebagai berikut:

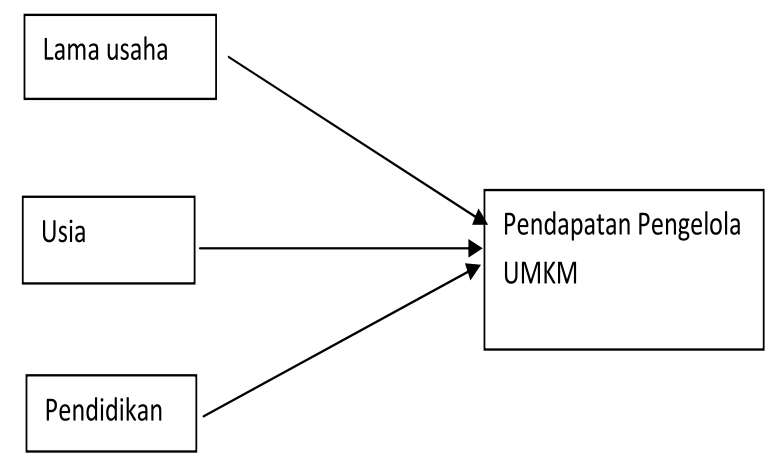

UMKM merupakan kependekan dari Usaha Mikro, Kecil dan Menengah, ialah kegiatan perekonomian yang jumlah aset dan omsetnya termasuk tenaga kerjanya berjumlah kecil atau menengah. UMKM ini menjadi perhatian pembinaan yang serius dari pemerintah. Ada beberapa alasan mengapa pemerintah menaruh perhatian besar pada UMKM. Jumlah pengelola UMKM cukup besar dan dapat menyerap tenaga kerja yang cukup banyak pula jumlahnya. UMKM ini merupakan aktifitas pengusaha mikro dan pemilik modal kecil, tetapi dapat menyerap tenaga kerja yang besar, UMKM dapat dikelola oleh rakyat yang pendidikannya rendah, berpengetahuan terbatas, tetapi bersemangat keras.

Usaha kecil perlu didorong perkembangannya guna memacu pertumbuhan perekonomian rakyat, guna meningkatkan kesejahteraan rakyat kecil yang bermodalkan kecil. Usaha kecil memiliki ciri khas dari usaha pada umumnya, ciri usaha kecil itu adalah:

Biro Pusat statistik mendefinisikan usaha kecil dengan ukuran tenaga kerja, yaitu 5-19 orang termasuk pekerja kasar yang dibayar, pekerja pemilik, dan pekerja keluarga. Perusahaan industri yang memiliki tenaga kerja kurang dari 5 orang diklasifikasikan sebagai industri rumah tangga (Suryana, 2001: 87).

Kriteria usaha kecil menurut Komisi untuk perkembangan ekonomi, mengemukakan (Suryana, 2003 : 87-88), kelemahan usaha kecil:

a. Manajemen berdiri sendiri, manajer adalah pemilik

b. Modal disediakan oleh pemilik atau sekelompok kecil

c. Daerah operasi bersifat lokal

d. Ukuran dalam keseluruhan relatif kecil

e. Memiliki kebebasan untuk bertindak

f. Fleksibel

g. Tidak mudah goncang

h. Lemah secara struktural, lemah secara kultural

Menurut Murti Sumarni dan John Suprihanto (2003: 10), perusahaan kecil dikelola dipimpin oleh pemiliknya, struktur organisasi sederhana, kegagalan relatif tinggi dan kesulitan pengembangan dikarenakan sulit memperoleh pinjaman.

Undang Undang UMKM tahun 2008 pada pasal 6 ayat 1 sampai ayat 3 memerinci kriteria 
UMKM dari sisi besarnya asset usaha sebagai berikut: Usaha mikro memiliki kekayaan bersih paling banyak Rp. 50.000,000,-(lima puluh juta rupiah) atau memiliki hasil penjualan paling banyak 300.000.000,- (tiga ratus juta rupiah). Usaha kecil menurut pasal tersebut dinyatakan, memiliki kekayaan lebih dari 50.000.000 (lima puluh juta rupiah) paling banyak 500.000.000,- (lima ratus juta rupiah), tidak termasuk tanah dan bangunan, atau memiliki hasil penjualan tahunan lebih dari 300.000.000,- (tiga ratus juta rupiah) sampai dengan paling banyak 2.500.000.000,- (dua milyard lima ratus ribu rupiah). Usaha menengah dinyatakan memiliki kekayaan bersih lebih dari 500.000.000,- (lima ratus juta rupiah) sampai dengan paling banyak 10.000.000.000,-(selupuh milyard rupiah) tidak termasuk tanah dan bangunan tempat usaha. Atau memiliki hasil penjualan tahunan lebih dari 2.500.000.000,- (dua milyar rupiah) sampai dengan 50.000.000.000,- ( lima puluh milyar rupiah), tidak termasuk tanah dan bangunan.

\section{Pengembangan UMKM}

Ada beberapa problem yang dialami para pengelola UMKM dalam pengembangan usaha saat ini, antara lain: terbatasnya pengetahuan pengelola tentang kualitas produk, keterbatasan akses pasar dan pemasaran usaha, keterbatasan modal dan keterbatasan jiwa entrepreneur. Keterbatasan -keterbatasan usaha itu akan menjadi problem menghambat perkembangan usaha pengelolaan UMKM yang perlu dicarikan solusinya.

Adapun upaya solusi itu antara lain: pengembangan wawasan produk usaha, pengembangan akses pasar dan pemasaran, pengembangan akses modal dan pengembangan entrepreneur.

1. Strategi pengembangan produk usaha

Produk merupakan segala hal yang dapat ditawarkan kepada pihak lain untuk memenuhi kebutuhan konsumen. Pengelola UMKM menganalisis jenis usaha yang dibutuhkan pasar, apakah yang dibutuhkan kuantitasnya, atau kebutuhan lainnya. Hal ini tentu disesuaikan dengan segmen pasar yang dipilihnya. UMKM yang menyediakan berbagai produk untuk golongan kelas menengah ke atas memerlukan produk kualitas tinggi, tempatnya bersih, nyaman dan layanan baik; masalah harga tidak menjadi soal, karena konsumen kelas atas pada umumnya berduit, produk yang harganya sedikit lebih mahal dari produk lain tak masalah asal kebutuhan terpenuhi. Mempertimbangkan bahwa konsumen sangat heterogen kondisinya, maka pengembangan produk diarahkan pada dua model ialah (1) diversifikasi produk yang akan dapat memenuhi berbagai segmen pasar yang masih heterogen. (2) segmentasi pasar, targeting pasar dan positioning produk.

2. Pengembangan akses pasar dan pemasaran

Akses pasar dan pepasaran menjadi kunci kesuksesan pengelolaan UMKM, betapapun bagus kualitas produksi, banyak jumlah produk yang dihasilkan, bila gagal memasarkan usaha, maka akan menjadi gagal bisnis yang dijalani. Ada tiga akses pasar yang harus dipahami pengelola UMKM, ialah pasar konsumen, pasar industri dan pasar reseller. Pengelola UMKM bisa melayani ketiga pasar, dua pasar atau bisa juga hanya melayani satu pasar saja.

Pasar konsumen berarti produk dipasarkan dan dibeli oleh konsumen untuk dikonsumsi sendiriatau keluarga, pasar ini sedikit kuantitas kebutuhan, tetapi sangat besar frekuensi pembeliannya dan harga pembeliannya bisa relative lebih tinggi. Pasar reseller, pembeli produk melakukan penjualan kembali kepada pasar. Pasar industry, pembeli membeli produk untuk diproses produk kembali diperusahaan. Pasar reseller maupun pasar industry rata rata 
tingkat pembeliannya rendah, tetapi jumlah pembeliannya lebih besar. Pengelola UMKM harus mampu membaca pasar mana yang dipilih dan yang menguntungkan, termasuk di mana pasar itu berada, bagaimana mencari pasar dan bagaimana melayani pasar. Promosi dan publikasi sangat diperlukan untuk dapat mendapatkan jaringan akses pasar, dalam menciptakan brand dan menjadikan kebanggaan konsumen akan produk yang dikonsumsinya.

3. Pengembangan akses modal

Membuka usaha UMKM harus memiliki modal yang cukup untuk membiayai usahanya. Para pengelola UMKM kadang mengalami kesulitan modal dikala akan melakukan usaha awal, pengembangan maupun di kala usahanya mengalami kemunduran. Akses modal sebenarnya jaringannya ke bank, tetapi problem yang banyak dialami para pengelola UMKM adalah bagaimana bisa mendapatkan modal yang cukup dan tanpa agunan. Para pengelola UMKM rata-rata berekonomi lemah, tidak memiliki kelonggaran agunan kredit, sehingga para pengelola UMKM mengharapkan kredit yang dijalani dapat diperoleh tanpa harus menggunakan agunan.

\section{Umur, pengalaman dan pendidikan pengelola UMKM}

Usaha pengelolaan UMKM merupakan pekerjaan yang memerlukan ketrampilan, ketekunan dan pengalaman pengelolaannya. Umur seseorang merupakan standar kematangan diri, semakin tua umur seseorang semakin mengendap emosinya, semakin telaten dan tekun mengelola usaha UMKMnya, merasa di bidang usaha itu yang tepat mereka tidak akan beralih pada usaha yang lain, manakala umur masih muda kebanyakan akan mencari pengalaman atau memilih jenis pekerjaan yang lebih bergengsi, pikirannya belum mengendap, masih labil akan pemilihan bidang kerjanya.

Pengalaman mengelola UMKM dapat menjadi faktor keberhasilan usaha, baik pengalaman mencari bahan baku yang lebih murah, pengalaman komunikasi mencari pelanggan maupun pengalaman membuat produk yang disenangi pasar.

Pengelolaan UMKM tidak cukup ditangani oleh orang yang berpengalaman, tetapi diperlukan kemampuan menganalisis perkembangan lingkungan, analisis potensi dan berbagai kebijakan pemerintah. Untuk bisa melakukan itu semua seorang pengelola UMKM diperlukan personal yang berpendidikan

Sejalan dengan upaya pengelolaan UMKM sebagai kegiatan wirausaha, keberhasilan berwirausaha menurut Suryono, (2001:44), ditentukan oleh: kemampuan dan kemauan, tekad yang kuat dan kerja keras, kesempatan dan peluang. Pendapatan pengelola UMKM merupakan wujud keberhasilan mengelola usaha, besarnya usaha pada umumnya saling berkorelasi dengan pendapatan yang diperoleh. Atas besaran usaha akan memberikan kontribusi yang lebih besar, atas pendapatan yang diperoleh pengusaha berani mengembangkan usahanya yang lebih luas.

Pendapatan Pengelola UMKM dan Faktor yang mempengaruhi

Pendapatan merupakan perolehan imbalan atas usaha produk atau jasa yang dilakukan oleh pengelola UMKM terutama yang berwujud financial. Pendapatan merupakan hasil usaha yang telah dilakukan pada kurun waktu tertentu. Pendapatan bisa dilihat dalam kurun satu minggu, satu bulan, satu semester dan satu tahun. Rentangan dan kurun waktu yang pada umumnya dipakai sebagai waktu ukuran pendapatan adalah setiap satu bulan. 
Semua pengusaha atau pengelola UMKM selalu berusaha menperoleh pendapatan yang maksimal dari usaha yang dilakukan, dengan berbagai cara dan model masing-masing berdasarkan kemampuan masing-masing pula. Para pengelola UMKM yang telah banyak pengalaman mengelola usaha, mereka akan memiliki banyak korelasi, banyak trik-trik mengelola usaha sehingga lebih mampu menguasai strategi berbisnis yang akan banyak menguntungkan. Mereka yang pendidikannya lebih tinggi tentu wawasannya lebih luas, pengambilan kebijakan bisnisnya akan lebih tepat. Demikian pula pengelola UMKM yang memiliki tenaga kerja lebih banyak dimungkinkan akan memiliki pendapatan usaha yang lebih tinggi. Pengelola UMKM yang lebih lama usaha, berpendidikan lebih tinggi tentu lebih memahami di mana mencari peluang usaha, memahami peluang apa yang lebih menjanjikan. Pada akhirnya akan memberikan hasil yang maksimal.

\section{Hipotesis}

Mendasarkan pada teori dan kajian-kajian yang dikembangkan pada uraian dan halaman sebelumnya, rasanya tidak berlebihan jika penulis merumuskan hipotesis sebagai berikut:

1. Ada pengaruh lama usaha, usia dan, tingkat pendidikan secara simultan terhadap pendapatan para pengelola UMKM di Kabupaten Kulon Progo.

2. Ada pengaruh lama usaha, usia dan tingkat pendidikan secara parsial terhadap pendapatan para pengelola UMKM di Kabupaten Kulon Progo

\section{METODE PENELITIAN}

Populasi merupakan jumlah keseluruhan yang mencakup semua anggota yang diteliti (Istijono, 2005, 109). Keseluruhan obyek penelitian ini bisa sangat luas tanpa batas, bisa berada dalam batas areal tertentu tergantung definisi dari judul penelitian yang disusun. Populasi penelitian ini adalah seluruh pengelola UMKM di kabupaten Kulon Progo, Yogyakarta yang jumlahnya belum terdata.

Sampel penelitian sejumlah seratus pengelola UMKM Kulon Progo. Pengambilan sampel pada penelitian ini dengan purposive sampling, ialah pengambilan sampel dengan ketentuan-ketentuan tertentu yang ditetapkan peneliti. Sampel penelitian ini ditetapkan 100 orang, diambil pada 3 kecamatan dari 12 kecamatan yang ada di Kulon Progo. Penentuan tiga kecamatan itu dipertimbangkan satu kecamatan (Galur) mewakili daerah dataran rendah daerah pertanian, dua kecamatan (Lendah dan Sentolo) mewakili daerah dataran tinggi yang mayoritas daerahnya terdiri atas areal perkebunan dan hutan.

Data yang digunakan pada penelitian ini adalah data primer, data diambil semata untuk data penelitian ini; teknik pengumpulan data dengan menggunakan teknik kuesioner, data dianalisis secara diskripsi dengan tabulasi prosentase (data identitas diri responden) dan untuk mencari keterikatan antar variabel data akan dianalisis dengan statistik regresi berganda.

\section{HASIL PENELITIAN DAN PEMBAHASAN}

Pengembangan instrumen penelitian

Penelitian ini memiliki satu variabel dependen dan tiga variabel independen. Satu variabel dependen itu adalah pendapatan pengelola UMKM, sementara tiga variabel independennya adalah usia, lama usaha, dan tingkat pendidikan pengusaha pengelola UMKM di Kabupaten $\mathrm{Ku}-$ lon Progo. Variabel lama usaha dikembangkan menjadi $1 \mathrm{~s} / \mathrm{d} 5$ tahun (skor 1), $6 \mathrm{~s} / \mathrm{d} 10$ tahun (skor 2), $11 \mathrm{~s} / \mathrm{d} 15$ tahun (skor 3), $16 \mathrm{~s} / \mathrm{d} 20$ tahun (skor 4) dan di atas 20 tahun (skor 5). Variabel usia diklasifikasi menjadi lima kategori : usia an- 
$\operatorname{tara} 20 \mathrm{~s} / \mathrm{d} 30$ tahun (skor 1), usia antara $31 \mathrm{~s} / \mathrm{d} 40$ tahun (skor 2), usia antara $41 \mathrm{~s} / \mathrm{d} 50$ tahun (skor 3), usia antara $51 \mathrm{~s} / \mathrm{d} 60$ tahun (skor 4) dan usia di atas 60 tahun (skor 5).

Variabel tingkat pendidikan diklasifikasi menjadi : tak tamat SD (skor 1), tamat SD (skor 2), tamat SMP (skor 3), tamat SLTA (skor 4), tamat Diploma (skor 5), Sarjana (skor 6).:

Variabel pendapatan usaha, dikembangkan menjadi 6 klasifikasi, pendapatan kurang dari 3 juta (skor 1), pendapatan antara 3,1 s/d 6 juta (skor 2), pendapatan antara 6,1 sampai 9 juta (skor 3), pendapatan antara 9,1 s/d 12 juta (skor 4), pendapatan antara 12,1 s/d 15 juta (skor 5) dan pendapatan di atas 15 juta perbulan (skor 6).

Instrumen penelitian didisain mengikuti konstruk validity, logical validity maupun contens validity. Untuk selanjutnya instrumen tidak perlu dicari tingkat validitas dan reliabilitasnya, karena instrument sifatnya mencari data global, pertanyaan jelas, mudah dipahami oleh responden.

Pelaksanaan Penelitian (Penyebaran angket) dan Diskripsi Data

Angket penelitian yang telah disusun dengan baik, diedarkan berjumlah 100 eksemplar, ternyata kembali 89 , dua (2) eksemplar kembali tidak lengkap pengisiannya yang tidak bisa dianalisis dan empat (4) eksemplar angket dikembalikan utuh. Dengan demikian terdapat 83 angket yang dapat di analisis dan disajikan dalam laporan penelitian. Diskripsi data responden sebagai berikut:

Kondisi responden penelitian yang terdiri atas 83 sampel (responden) dari keseluruhan pengelola UMKM di Kabupaten Kulo Progo berada pada kondisi yang bervariasi dipandang dari berbagai sisi. Dipandang dari sisi lama usaha yang dilakukan pengelola UMKM di Kulon Progo, terdapat 20 orang $(24 \%)$ lama usahanya $1-5$ tahun, terdapat 33 orang ( $39,7 \%$ ) lama usa- hanya 6-10 tahun, terdapat 11 orang $(13,2 \%)$ lama usahanya 11-15 tahun, terdapat 12 orang (14,5\%) lama usahanya 16-20 tahun dan terdapat 7 orang ( $8,4 \%$ ) yang lama usaha mengelola UMKM diatas 20 tahun. Uraian itu dapat dilihat pada tabel berikut:

\section{Tabel 1}

Lama usaha para pengelola UMKM

\begin{tabular}{|c|l|c|c|}
\hline No & $\begin{array}{c}\text { Lama mengelola } \\
\text { UMKM }\end{array}$ & Frekuensi & Presentasi \\
\hline 1 & $1-5$ tahun & 20 & 24 \\
\hline 2 & $6-10$ tahun & 33 & 39,7 \\
\hline 3 & $11-15$ tahun & 11 & 13,2 \\
\hline 4 & $16-20$ tahun & 12 & 14,5 \\
\hline 5 & 21 tahun ke atas & 7 & 8,4 \\
\hline & Total & 83 & 100 \\
\hline
\end{tabular}

Klasifikasi usia pengelola UMKM, atas hasil pengumpulan data dari seluruh responden, terdapat 7 orang $(8,4 \%)$ yang berusia di bawah 30 tahun, terdapat 30 orang $(36,1 \%)$ berusia antara $31-40$ tahun, terdapat 25 orang (30\%) berusia antara 41-50 tahun, terdapat 19 orang (23\%) yang usia mereka antara 51-60 tahun dan hanya 2 orang $(2,4 \%)$ yang berumur di atas 60 tahun. Selanjutnya untuk memahami kondisi usia pengelola UMKM di Kabupaten Kulon Progo disajikan dalam table berikut:

Tabel 2

Usia Pengelola UKM

\begin{tabular}{|c|l|c|c|}
\hline No & Usia pengelola UMKM & Frekuensi & Presentasi \\
\hline 1 & $21-30$ tahun & 7 & 8,4 \\
\hline 2 & $31-40$ tahun & 30 & 36,1 \\
\hline 3 & $41-50$ tahun & 25 & 30 \\
\hline 4 & $51-60$ tahun & 19 & 23 \\
\hline 5 & Di atas 60 tahun & 2 & 2,4 \\
\hline & Total & 83 & 100 \\
\hline
\end{tabular}

Tingkat pendidikan para pengelola UMKM masyarakat Kulon Progo, mayoritas berpendidikan SLTA ke atas, hanya 5 orang $(6 \%)$ berpendidikan SD, 7 orang responden $(8,4 \%)$ berpen- 
didikan SMP, 50 orang $(60,2 \%)$ berpendidikan SLTA, 7 orang $(8,4 \%)$ pengelola UMKM berpendidikan sarjana muda dan sejumlah 14 orang responden $(16,9 \%)$ berpendidikan sarjana. Untuk mempermudah membaca data dapat dilihat table berikut:

Tabel 3

Tingkat Pendidikan Pengelola UKM

\begin{tabular}{|c|l|c|c|}
\hline No & $\begin{array}{c}\text { Pendidikan pengelola } \\
\text { UMKM }\end{array}$ & Frekuensi & presentasi \\
\hline 1 & Tak tamat SD & - & \\
\hline 2 & Tamatan SD & 5 & 6 \\
\hline 3 & Tamatan SMP & 7 & 8,4 \\
\hline 4 & Tamatan SLTA & 50 & 60,2 \\
\hline 5 & Tamatan Sarjana muda & 7 & 8,4 \\
\hline 6 & Sarjana & 14 & 16,9 \\
\hline & Total & 83 & 100 \\
\hline
\end{tabular}

Pendapatan hasil usaha pengelola UMKM setiap bulan, berdasar data yang diperoleh dapat dilaporkan sebagai berikut:

Terdapat 6 responden $(7,2 \%)$ berpendapatan perbulan kurang dari 3 juta rupiah, 42 responden $(50,6 \%)$ berpendapatan antara 3,1 sampai 6 juta rupiah, 10 responden $(12 \%)$ berpendapatan perbulan antara 6,1 sampai 9 juta rupiah , 9 responden $(10,8 \%)$ berpendapatan antara 9,1 sampai 12 juta rupiah, 3 responden ( 3,6 \%) berpendapatan antara 12,1 sampai 15 juta rupiah dan 13 responden $(15,7 \%)$ berpendapatan di atas 15 juta rupiah. Tabel berikut membantu mempermudah memahami pendapatan responden:

\section{Tabel 4}

Pendapatan per bulan Usaha UKM

\begin{tabular}{|c|l|c|c|}
\hline No & \multicolumn{1}{|c|}{$\begin{array}{c}\text { Pendapatan Usaha } \\
\text { perbulan }\end{array}$} & Frekuensi & Presentasi \\
\hline 1 & Kurang dari 3 juta & 6 & 7,2 \\
\hline 2 & Antara 3,1 sampai-6 juta & 42 & 50,6 \\
\hline 3 & Antara 6,1 sampai 9 juta & 10 & 12 \\
\hline 4 & Antara 9,1 sampai 12 juta & 9 & 10,8 \\
\hline 5 & Antara 12,1 sampai 15 juta & 3 & 3,6 \\
\hline 6 & Di atas 15 juta & 13 & 15,7 \\
\hline & Total & 83 & 100 \\
\hline
\end{tabular}

Hasil pengumpulan data yang diperoleh atas isian angket oleh para responden, data entry dalam tabelisasi progran Exel, data dianalisis guna membuktikan kebenaran hipotetsis yang dirumuskan.

\section{Analisis Data}

Hasil analisis variabel lama usaha, usia pengusaha dan tingkat pendidikan pengusaha pengelola UMKM sebagai X1, X2, $\mathrm{X} 3$, terhadap pendapatan pengelola UMKM sebagai variabel $\mathrm{Y}$, secara simultan $\mathrm{X}$ 1, X2 dan X3 berpengaruh terhadap Y. Berdasar hasil analisis menggunakan statistik program SPSS, dapat dilihat pada tabel berikut:

Tabel 5

\section{Uji F Variabel Dependen - Pendapatan Pengelola UMKM}

Anova(b)

\begin{tabular}{|c|c|c|c|c|c|c|}
\hline Model & & $\begin{array}{l}\text { Sum of } \\
\text { Squares }\end{array}$ & Df & $\begin{array}{l}\text { Mean } \\
\text { Square }\end{array}$ & $\mathrm{F}$ & Sig. \\
\hline \multirow[t]{3}{*}{1} & Regression & 23.524 & 3 & 7.841 & 3.290 & $.025(a)$ \\
\hline & Residual & 188.283 & 79 & 2.383 & & \\
\hline & Total & 211.807 & 82 & & & \\
\hline
\end{tabular}

a Predictors: (Constant), X3, X2, X1

b Dependent Variable: $Y$

Hasil perhitungan regresi berganda pada tabel di atas dapat diketahui tingkat signifikannya, bahwa variabel usia pengusaha (X1), lama usaha (X2), pendidikan pengusaha (X3) secara simultan berpengaruh secara signifikan terhadap pendapatan pengelola UMKM (Y). Atas dasar ketiga variabel itu dengan $\mathrm{N} 83$ nilai $\mathrm{F}$ hitungnya sebesar 3,290 dan signifikansinya 0,025 , yang berarti secara bersama - sama ketiga variabel bebasnya (X1, X2, dan X3 ) berpengaruh secara signifikan terhadap variabel terikat pendapatan $(\mathrm{Y})$ pengelola UMKM di Kabupaten Kulon Progo, tingkat signifikannya pada probabilitas $5 \%$.

Selanjutnya data dianalisis dengan regresi secara parsial analisis pengaruh beberapa variabel 
secara terpisah, satu persatu terhadap satu variabel lain, hasilnya pengaruh variabel independen lama usaha, usia dan pendidikan (X1, X2 dan X3) secara parsial terhadap variabel dependen Y (pendapatan) pengelola UMKM, dapat dilihat pada tabel berikut:

Tabel 6

Uji T Varibel Dependen - Pendapatan Pengelola UMKM

Coefficients(a)

\begin{tabular}{|cc|c|c|c|c|c|}
\hline \multicolumn{2}{|c|}{$\begin{array}{c}\text { Mod- } \\
\text { el }\end{array}$} & \multicolumn{2}{|c|}{$\begin{array}{c}\text { Unstandard- } \\
\text { ized Coef- } \\
\text { ficients }\end{array}$} & $\begin{array}{c}\text { Standard- } \\
\text { ized Coef- } \\
\text { ficients }\end{array}$ & $\mathrm{t}$ & Sig. \\
\hline & & $\mathrm{B}$ & $\begin{array}{c}\text { Std. } \\
\text { Error }\end{array}$ & Beta & $\mathrm{B}$ & Std. Error \\
\hline 1 & (Constant) & .793 & 1.116 & & .711 & .479 \\
& $\mathrm{X} 1$ & .048 & .031 & .213 & 1.523 & .132 \\
& $\mathrm{X} 2$ & -.194 & .221 & -.119 & -.878 & .382 \\
& $\mathrm{X} 3$ & .528 & .186 & .343 & 2.834 & .006 \\
\hline
\end{tabular}

a Dependent Variable: Y

Hasil analisis menunjukkan bahwa variabel $\mathrm{Xi}$ dan $\mathrm{X} 2$ secara parsial tidak berpengaruh terhadap variabel $Y$. Khusus untuk variabel independen (X3) tingkat pendidikan berpengaruh terhadap variabel dependen pendapatan sebagai (Y ) dengan tingkat signifikansi 0,006 yang berarti tingkat pendidikan berpengaruh secara signifikan untuk signifikansi $5 \%$ maupun $1 \%$ terhadap pendapatan pengelola UMKM di Kulon Progo.

\section{KESIMPULAN DAN SARAN}

Mendasarkan pada analisis yang dilaporkan pada bab sebelumnya, atas hasil analisis itu dapat disampaikan beberapa kesimpulan yang dapat diambil dalam penelitian ini, antara lain:

1. Secara simultan terdapat pengaruh positif dan signifikan variabel lama usaha, usia pengusaha dan tingkat pendidikan terhadap pendapatan pengelola UMKM di Kabupaten Kulon Progo Yogyakarta, dengan F hitung 3.290 dan tingkat signifikansi sebesar 0,025.
2. Secara parsial, terdapat pengaruh positif dan signifikan antara variabel tingkat pendidikan pengusaha terhadap pendapatan pengelola UMKM di Kabupaten Kulon Progo, Yogyakarta dengan $\mathrm{T}$ hitung (2.834) dan tingkat signifikansi 0,006

3. Secara parsial tidak terdapat pengaruh yang signifikan antara lama usaha dan tingkat usia terhadap pendapatan pengelola UMKM di Kabupaten Kulon Progo, Yogyakarta.

Berdasar kesimpulan atas hasil analisis yang telah dilakukan, maka ada beberapa rekomendasi yang disampaikan dengan harapan dapat membawa manfaat pada pihak terkait di kemudian hari:

Bagi lembaga pengembang bisnis, bagi pemerintah atau lembaga swasta

a. Sebaiknya para pelaku bisnis, para pengelola UMKM perlu difasilitasi, didorong, disemangati agar mereka sanggup meningkatkan belajar menambah pengetahuan terutama yang masih muda untuk meningkatkan pendidikannya.

b. Perlu diberikan pendidikan non formal bagi para pengelola bisnis dengan berbagai kursus dan pelatihan, selain meningkatkan ketrampilan usaha (skill), akan menambah wawasan lebih makro, terutama di masa global seperti sekarang ini, para pengelola bisnis sangat perlu mengetahui perkembangan luar dan perlu luasnya wawasan, sehingga akan memiliki kebijakan lebih makro dalam bisnisnya.

Bagi Pelaku bisnis

a. Menyadari bahwa kesuksesan pengusaha di masa persaingan bebas lebih banyak ditentukan atas luasnya wawasan dan keberanian mengambil resiko bisnis. Dengan hasil penelitian bahwa pendidikan sangat berpengaruh secara signifikan terhadap pendapatan maka para pengelola UMKM sebaiknya terus menambah pengetahuan, baik secara formal 
maupun secara informal demi perbaikan pendapatan usaha dan perbaikan perkembangan usaha yang dilakukan.

b. Penambahan pengetahuan (pendidikan) termasuk pelatihan-pelatihan bagi para pengelola bisnis yang masih muda lebih diutamakan pendidikan pengelolaan UMKM seperti jiwa kewirausahaan, peningkatan penguatan jiwa kewirausahaan dapat menambah matangnya pengelolaan UMKM, sebaiknya sambil secara terur-menerus menambah pengetahuan, sambil terus menjalani usahanya, pada saatnya akan semakin meningkat pendapatan pengelola UMKM.

Bagi Akademisi dan Peneliti

a. Penelitian yang dilakukan memang masih terbatas sampelnya 83 pengelola UMKM, maka kepada peneliti berikutnya supaya dilakukan penelitian yang lebih luas, lebih cermat agar bisa didapatkan data yang lebih akurat dengan didapat kesimpulan yang lebih kuat.

b. Belum didapatkannya jumlah populasi pengelola UMKM di Kulon Progo secara menyeluruh, termasuk tingkat usahanya, sehingga apabila penelitian bisa menyeluruh data dapat diperoleh lebih lengkap sebagai bahan analisis lebih akurat.

c. Hasil penelitian ini meskipun disana sini masih banyak kelemahan, semoga dapat dijadikan bahan dasar untuk penelitian berikutnya yang lebih detil dan mendalam, sehingga hasilnya akan lebih akurat.

\section{DAFTAR PUSTAKA}

Amir, M. Taufik (2004), Pemasaran Ritel, Panduan Lengkap Pengelolaan Toko Modern, PPM, Jakarta.

Ann Wan Seng (2007), Rahasia Bisnis Orang Korea (terjem.), Hikmah, Jakarta
Ciptono, Fandy,(1977) Strategi Pemasaran, Andy, Yogyakarta.

Chairina R., Genta P. \& Lastya A., (2008) Panduan Sukses Mendirikan dan Mengelola Rumah Makan Padang, Trans Media, Jakarta.

Faisol (2002) Kalau Begitu Saya berani Berwirausaha: PT Bina Rena Pariwara, Bogor.

Frans M. Royan (2007), Membuka Toko, Alternatif Usaha Mandiri: Effhar Offset, Semarang.

Gibson, Ivancevich, Donnelly(1996); Organisasi Perilaku, Struktur Dan Proses (terjem) Jilid I Ed. 5: Erlangga, Jakarta.

Irawan, Farid Wijaya dan Sudjoni (1996), Pemasaran Prinsip dan Kasus : BPFE, Yogyakarta

Istijanto, (2005), Aplikasi Praktis, Riset Pemasaran, Gramedia, Jakarta

Kotler, Philip dan Armstrong(2004), Dasar dasar pemasaran, Edisi sembilan Jilid 1 (terjem), Jakarta

Musyri'ah Hanum (2004), Kiat Menekuni Bisnis Catering, Warung Tenda Angkringan, Lengkap dengan Analisis Usaha, Absolut, Yogyakarta.

Murti Sumarni dan John Supriyanto (2003), Pengantar Bisnis Dasar-dasar Ekonomi Perusahaan, Liberty, Yogyakarta.

RI, 2008, Undang-Undang Republik Indonesia nomor 20 tahun 2008 tentang Usaha Mikro, Kecil dan Menengah, Lembaran Negara Rebublik Indonesia, Jakarta.

Sugiyono, (2007), Metode Penelitian Bisnis, Alfabeta, Bandung

Suryana (2008) Kewirausahaan, Pedoman Praktis, Kiat dan Proses Menuju Sukses, Salemba, Jakarta.

Wasty Soemanto,(1999), Pendidikan Wiraswasta: Bumi Aksara, Jakarta 